\title{
Pyoderma gangrenosum of the abdominal wall
}

\author{
Philip Samuel John Hall, ${ }^{1}$ Joe Houghton, ${ }^{2}$ Susannah Hoey, ${ }^{3}$ \\ Gaurav Prakash Manikpure ${ }^{1}$
}

${ }^{1}$ Department of Hepatology/ Gastroenterology, Royal Victoria Hospital, Belfast, UK ${ }^{2}$ Department of Pathology, Queens University Belfast, Belfast, UK

${ }^{3}$ Department of Dermatology, Royal Victoria Hospital, Belfast, UK

\section{Correspondence to} Dr Philip Samuel John Hall, phall03@qub.ac.uk

\section{DESCRIPTION}

A 60-year-old woman presented with a large painful haemorrhagic ulcer of her left lower abdomen. Her medical history included ulcerative colitis, breast cancer, stroke and atrial fibrillation for which she was on warfarin. On examination she had a $15 \times 6 \mathrm{~cm}$ large necrotic haemorrhagic ulcer of the left lower abdomen (figure 1). The border appeared violatious and undermined and the ulcer was malodorous. There was a history of trauma at the site of ulcer 2 months previously and the ulcer had since progressed. The differential diagnosis included warfarin necrosis and pyoderma gangrenosum. Biopsy specimen (figure 2) of the ulcer revealed ulceration and florid active chronic inflammation extending throughout the dermis and into subcutaneous fatty tissue confirming the clinical impression of pyoderma gangrenosum. She was started on oral prednisolone $30 \mathrm{mg}$ and dapsone $50 \mathrm{mg}$ daily along with regular dressings. The area of pyoderma gangrenosum showed good evidence of healing with borders appearing much flatter with evidence of shrinkage. Pyoderma gangrenosum of abdominal wall is rare and needs careful clinical and histopathological evaluation.

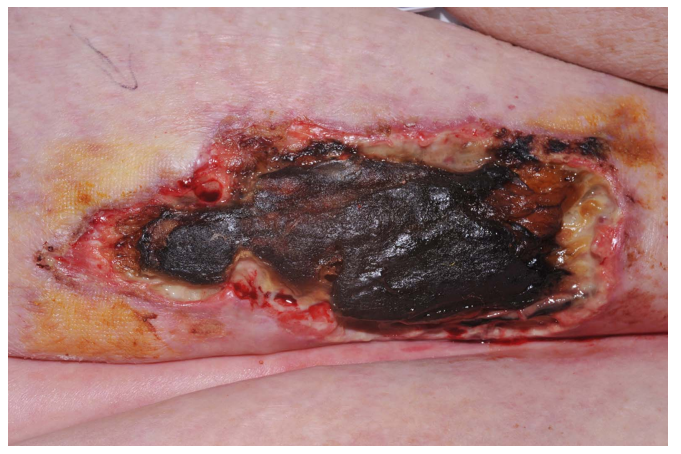

Figure 1 Violatious haemorrhagic ulcer of the left abdominal wall.

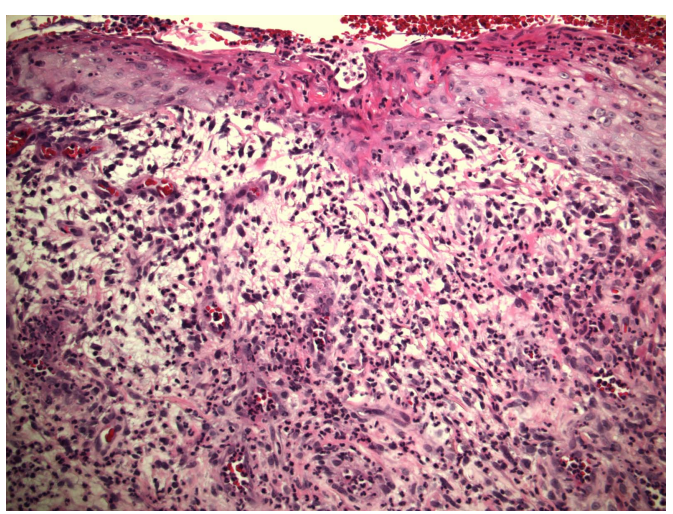

Figure 2 Intense intraepidermal and intradermal active chronic inflammation, while not specific, is consistent with pyoderma gangrenosum.

\section{Learning points}

- Pyoderma gangrenosum falls in the spectrum of neutrophilic dermatoses, inflammatory disorders that have in common a tendency for pathergy, as demonstrated in this case.

- Although rare, pyoderma gangrenosum can involve the abdominal wall and the early involvement of a dermatologist is extremely useful for proper diagnosis and management.

Contributors GPM created the manuscript and was involved with patient care. SH was involved in making the diagnosis and $\mathrm{JH}$ with analysis of the pathological specimen. All authors have reviewed and had input into the manuscript.

Competing interests None.

Patient consent Obtained.

Provenance and peer review Not commissioned; externally peer reviewed.
To cite: Hall PSJ,

Houghton J, Hoey S, et al. BMJ Case Rep Published online: [please include Day Month Year] doi:10.1136/ bcr-2013-201438 
Copyright 2013 BMJ Publishing Group. All rights reserved. For permission to reuse any of this content visit http://group.bmj.com/group/rights-licensing/permissions.

BMJ Case Report Fellows may re-use this article for personal use and teaching without any further permission.

Become a Fellow of BMJ Case Reports today and you can:

- Submit as many cases as you like

- Enjoy fast sympathetic peer review and rapid publication of accepted articles

- Access all the published articles

- Re-use any of the published material for personal use and teaching without further permission

For information on Institutional Fellowships contact consortiasales@bmjgroup.com

Visit casereports.bmj.com for more articles like this and to become a Fellow 